\title{
DEALING WITH THE PAST: PROSECUTION AND PUNISHMENT OF COMMUNIST CRIMES IN CENTRAL AND EASTERN EUROPEAN COUNTRIES

\author{
LIDAR COM O PASSADO: PROCESSOS PENAIS E PUNIÇÃO DE CRIMES \\ COMUNISTAS NA EUROPA CENTRAL E ORIENTAL
}

Martin Faix"

Ondrej Svacek ${ }^{* *}$

\begin{abstract}
This article addresses issues arising in the context of transition to democracy in Central and Eastern Europe, namely in Germany (former East Germany), Czech Republic, Slovakia and Hungary. The contribution reflects various means of transitional justice which were applied in these countries: access to the archives of secret police, lustration and prosecution of the crimes of the past (successor trials). Central issue of this article is the criminal prosecution of communist crimes. Here authors focus their attention on two interrelated aspects: choice of applicable law and statutory limitations, which both are linked to the principle of legality. Practice and methods in prosecution of the communist crimes adopted across the analyzed countries reveal considerable heterogeneity and from comparative perspective pose a unique legal laboratory. Despite differences in applicable law, including treatment and interpretation of statutory limitations, and differences in overall outcomes of prosecution and punishment of the communist crimes, all countries were conformed to requirements of the principle of legality. The article thus confirms that states, when dealing with their past, enjoy a wide margin of appreciation.
\end{abstract}

Keywords: Communist crimes. Central and Eastern Europe. Transitional justice. Successor trials. Nullum crimen sine lege.
Resumo: Este artigo aborda questões que surgem no contexto da transição democrática da Europa Oriental e Central, nomeadamente na Alemanha (antiga Alemanha Oriental), República Checa, Eslováquia e Hungria. A contribuição reflete vários meios de justiça de transição que foram aplicados nesses países: acesso a arquivos da polícia secreta, expurgo e repressão a criminosos do passado (processos posteriores). Uma questão central deste artigo é a persecução criminal de criminosos comunistas. Os autores concentram atenção em dois aspectos inter-relacionados: a escolha da lei aplicável e as limitações jurídicas existentes, ambos vinculados ao princípio da legalidade. Práticas e métodos de acusação por crimes do regime comunista adotados em todos os países analisados revelam uma considerável heterogeneidade mas, da perspectiva comparativa, é um só laboratório jurídico. Apesar das diferenças entre as leis aplicáveis, incluindo o tratamento e a interpretação de limitações legais, $e$ das diferenças nos resultados globais de julgamento e punição por crimes praticados durante o regime comunista, todos os países se adequaram às exigências do princípio da legalidade. $O$ artigo confirma, assim, que os Estados, ao lidar com o seu passado, desfrutaram de ampla margem de discricionariedade e de apreciação.

Palavras-chave: Crimes comunistas. Europa Central e Oriental. Justiça de transição. Processos a posteriori. Nullum crimen sine lege.

\footnotetext{
* UDr, PhD, MJI at Charles University in Prague; Senior lecturer in international law and member of the Center for Excellence - Research Centre for Human Rights at the Charles University in Prague, Faculty of Law; Senior Lecturer in International Law at the Palacký University in Olomouc, Faculty of Law; Czech Republic; faix@prf.cuni.cz

** Senior lecturer in international law at the Palacký University in Olomouc, Faculty of Law; Czech Republic; ondrej. svacek@upol.cz
} 


\section{Introduction}

On $18^{\text {th }}$ November 1968, Johann Dick, the national of the FRD, was shot-to-death by Pavel Čada and other two border guards of the then Czechoslovakian People's Army. While picking mushrooms in the border area, but still on the territory of the Federal Republic of Germany (FRG), Mr. Dick was mistakenly believed to be a would-be-escapee from Czechoslovakia. In the rush of this situation, border guards had pursued him on the territory of the FRG, shot him to death and later dragged his body to the territory of Czechoslovakia (CADA et al., 2001). This case presents only a single pebble in the mosaic of communist injustice symptomatic for all countries in the Soviet sphere of interest in the second half of the $20^{\text {th }}$ century.

The death of Johann Dick and thousands other crimes were consciously disregarded by the former regimes as they served higher state interests. The communist injustices were investigated, prosecuted and punished only as a part of the wider transitional process starting in 1990s. The aim of this contribution is to evaluate approaches towards prosecution of the crimes committed during the former communist rule. The prosecution will be explored as one of the means of the transitional process in four Central and Eastern European Countries (CEE), namely Germany, the Czech Republic, Slovakia and Hungary, on their path to democracy, respect for human rights and the rule of law. This undertaking serves two purposes: to commemorate the past, because of usual shortness of historical memory, and to learn from the past, as experience gained in the CEE region might be transferred to other countries facing similar problems of prosecution of the crimes of the former regimes.

To achieve these goals, the article will in the first step provide broader context of transition and describe the different means of transitional justice which were applied by the CEE Countries. This will provide fundaments and create the framework for examination of the central issue of this contribution, which is the prosecution of communist crimes. Here authors will focus their attention on two interrelated aspects: choice of applicable law and statutory limitations.

\section{Providing a framework for assessing transitional justice - transition in central and eastern europe}

More than a quarter of century has passed the communist system in Central and Eastern Europe collapsed and its end marked the starting point of a truly exceptional, comprehensive and fundamental process of qualitative changes. During this period, the CEE countries launched a process of transition not only to market economies, but to democratic political regimes. The question was not to reform the previous system from the period before 1989, but to substitute it completely (KORNAI, 2006, p. 207-244). Hence, it seems accurate to denote this process of changes as "radical".

An aspect immanent to the time after the fall of the iron curtain was the struggling with the past. Searching for ways and adopting policies on how to deal 
with the crimes committed by the communist system (in the broadest sense) became a crucial part of the transition process, as without justice there is no peace in the society and without the peace no successful transition to democracy based on rule of law can be mastered. ${ }^{1}$ The CEE countries faced a difficult decision whether to prosecute communist crimes and persons responsible for them or to grant amnesties or pardons. Both paths are fraught with difficulties. Those which arose in connection with the decision to take the "prosecution" alternative, will be addressed in more detail in the course of this contribution.

Studies on the transition process in Central and Eastern Europe commonly consider the countries in the region as a homogeneous group, which shared the socialist past, i.e. the dominance of the Communist parties in the form of a one-party rule, political surveillance of citizens, criminal laws violating fundamental rights and freedoms (such as the freedom of association or freedom of expression), planned economy and existence of repressive components serving the Communist regime rather than rule of law (secret police) ( that the transition experience, especially as it regards the outcomes of the transition process, is common through the region. ${ }^{2}$

However, it should be noted for the purpose of defining the scope and validity of conclusions to be drawn in this contribution that the countries through the region have not responded to the transition challenges in the same way. They rather experienced quite an individual and unique process, ${ }^{3}$ for three main reasons. First, their starting positions for the transition varied as a result of differing actual political and economical legacies and conditions in 1989. ${ }^{4}$ Second, based on the different starting situation, the elites of the CEE countries have chosen transition approaches, which varied considerably from State to State, e.g. a rapid "shock therapy" approach to transition by Poland or the Czech Republic (HELICHER, 2000), compared to the rather gradualist approach of Slovakia. Third, the countries have shown a different level of commitment to reach the transition goals, which coping with the past was an important and integral part of (ASLUND, 2001).

\footnotetext{
1 Teitel (2000, p. 6) is relying on a similar idea, arguing that the conception of justice in periods of political changes is extraordinary and constructivist, i.e. "[...] it is alternately constituted by, and constitutive of, the transition."

2 The prominent Hungarian economist, Janos Kornai, names six most important common characteristics of the transformation process in the CEE region: 1 . The changes in the economic sphere were in the direction of the capitalist economic system; 2 . The changes in the political field were in the direction of democracy; 3 . A complete transformation took place in all spheres: in the economy, in the political structure, in the world of political ideology, in the legal system and in the stratification of society; 4 . The transformation was non-violent; 5 . The transformation took place under peaceful circumstances; 6 . The transformation took place with incredible speed (KORNAI, 2006, p. 217 et seq).

3 A good example is the Slovak Republic; in the period of authoritarian government of Vladimír Mečiar (1993-1998) the country remained politically isolated and economically and legally unreformed. In the period 1998 - 2004, i.e. until the accession to the EU, Slovakia managed with its transformation efforts not only to fulfill the criteria for the EU membership but, in several reform areas, it went even beyond the EU criteria.

4 For an analysis of historical legacies of the former communist countries and the impact of these legacies on the transition process and its outcome, see, for example, Pop-eleches (2007, p. 908-926).
} 
For the present issue of prosecution of communist crimes and the realization of the idea of transitional justice in general, especially the differing historical, political, social and economic legacies at the outset of transition were of considerable importance. The transition process for example in the former East Germany (German Democratic Republic) was to a large extent different, not least because of the extinction of the East Germany through its incorporation into the Federal Republic in Germany on the 3 October 1990. Some of the CEE countries were at the start of transition period firmly established States (e.g. Poland, Czechoslovakia), whereas some (re)gained independence (countries established on the ruins of Yugoslavia, Baltic States). For Yugoslav countries the disintegration of the common State constituted a significant struggle, despite Yugoslavia's own "type" of socialism, which the country developed and adopted since 1948, having made Yugoslavia one of the most prosperous States in the CEE region. This system allowed for example generally its citizens to travel abroad without visas or created an economic system, which appeared to offer a middle way between capitalism and Soviet central planning.

Also the strength (or weakness) of the communist regime in the CEE countries in 1989 and the way, in which they removed the regime, shaped the balance of power between former communists and their opposition in the post-1989 period, resulting in differing approaches and strategies, among others, towards transitional justice (NEDELSKY, 2009). Taking Czechoslovakia as an example, the "normalization" period, following the 1968 Prague Spring reform movement (suppressed, inter alia, through the invasion of the Soviet controlled Warsaw Pact troops), introduced a regime of political hardliners unable of any flexibility, refusing and resisting any kind of reforms, leading finally and inevitably to the collapse of the regime in 1989. The Velvet Revolution, which started on 17 November 1989 with a student demonstration, turned in just ten days into a general strike with millions people participating. The Communist leaders as representatives of the hardline "normalization" regime were not in position to demand any kind of compromise, as it was for example the case in Poland by way of the Roundtable Agreements. Consequently, the strong new leadership, which was gathered from newly established dissident-led parties, ${ }^{5}$ replaced the old Communist political elites in the course of the first free elections. Such a thorough change laid foundations for a more rigorous approach of the new Czecho-Slovak elites towards transitional justice, which was naturally more likely to follow the "prosecute and punish" than the "forgive and forget" path.

\section{Coping With The Past - By What Means?}

The varying historical legacy, but also differences in the paths to democracy and rule of law chosen after the fall of the Iron Curtain, influenced the CEE coun-

\footnotetext{
5 Občanské fórum/the Civic Forum (in the Czech part of the state) and the Verejnost' proti násiliu/Public against Violence (in Slovakia).
} 
tries' strategies towards transitional justice and resulted in trajectories with diverging endpoints. Nevertheless, it can be argued that most countries adopted three means in order to accomplish the idea of transitional justice: lustration, opening of the archives, and prosecution of communist crimes.

This article focuses on the issue of prosecution, which will be explored below, especially with regard to problematic legal aspects of this approach. However, in order to provide an accurate picture which would enable substantial understanding of prosecution of communist crimes as a mean of transitional justice, also further pieces of the mosaic need to be briefly addressed.

\subsection{Access to Archives}

The access to archives constitutes one of the three main pillars of decommunization and the process of transitional justice in Central and Eastern Europe. To understand how relevant the opening of the archives especially of the Secret Police $^{6}$ for the process of transition to democracy, rule of law and for the coping with the past (Geschichtsbewältigung) was, one has first to apprehend the role which the Communist Party and the Secret Police played.

The presence and significance of the Communist party for every sphere of life can be described as overwhelming. Similarly, the Secret Police as political police and repressive part of the communist regimes was omnipresent in the lives of the citizens. For example in Czechoslovakia, the Státní bezpečnost (StB) had some 9000 regular employees (NEDELSKY, 2009, p. 40) (the number needs to be seen in relation to the overall population, which was then about 15 million inhabitants) and in mid-1989 some 30000 collaborators (NEDELSKY, 2009, p. 41), creating a nation-wide network of informers and agents spying and providing information on the activities of their neighbors, colleagues, fellow students, and even family members. During the communist rule the secret police apparatus participated often in crimes and excesses of the regime, especially in the times of Stalinist terror (1950s), Warsaw Pact invasion and repression of the Prague Spring movement in 1968, and the following "normalization" period (1970s). In the overall period between 1948 and 1989, the regime sentenced for political reasons some 250000 people (NEDELSKY, 2009, p. 41), thousands of which died as a consequence of physical violence in prisons, were executed or died because of conditions in labor camps and uranium mines. Opening of the secret policy archives thus serves important purposes. It provides access for those who suffered under the communist regime (victims), enables vetting of current public officials for involvement with communist regime and finally provides evidence for trials with persons who participated in crimes and excesses or persons responsible for the repression apparatus (perpetrators).

$\overline{{ }_{6}}$ For example, STASI (Staatssicherheit/Secret police) in East Germany, StB (Státní bezpečnost) in Czechoslovakia. 


\subsection{Lustration}

Lustration denotes the process of screening individuals occupying influential posts in political or economic sphere with the aim to determine whether, and if so, to what extent, they collaborated with the former secret police, for example in East Germany the STASI, in former Czechoslovakia the StB. Lustration, which in some of the countries was denoted rather as "debolshevization" or "decommunization", became a frequent and widely used, although not necessarily a consequently applied mean of transitional justice. Only in two CEE countries, East Germany and the Czech Republic, lustration laws were passed and put into real life. In Slovakia for example, a lustration law was adopted, but due to a low level of political commitment it was never applied until its expiration. Lustration process has however begun already before Czechoslovakia's disintegration in 1993. Its first milestone was the passing of the respective law on October 4, 1991, which introduced lustration on a person-by-person basis. Lustrated persons were divided into three categories: agents of the secret police, informers or owners of conspiratorial apartments belonged to the "A" category of collaborators, "B" category comprised "conscious collaborators" registered as "trustees" of the regime and its secret police. Third category, i.e. "C" category comprised persons who were mere candidates for collaborators. The category $\mathrm{C}$ was later repealed. The lustration laws applied to judges and prosecutors and persons occupying top posts in a broad range of institutions, such as in Czechoslovak colleges and universities, television and radio, or the state press agency. A negative lustration certificate was required for employees of the Ministry of the Interior or the Federal Security and Information Services.

Already during setting up the lustration laws and system, problematic aspects of this method of reaching justice became apparent. One of the problems was identification of criteria, on the basis of which certain person will become object of lustration or prosecution. This is in the context of authoritarian regimes an extremely problematic task, simply because large groups of the people/inhabitants served the regime in a more or less intensive way. In other words, the line between victims, by-standers, and perpetrators might be thin and to distinguish precisely between the categories is complicated, if not impossible. Tismaneanu (2009, p. 37) considers the attempt to draw the boundaries between them even as "elusive". Consequently, many opposed lustration as a mean, which is based on the principle of collective guilt. As Šiklová (1999, p. 249) writes, even President Václav Havel "[...] opposed the lustration law because of its implicit presumption of guilt rather than of innocence." Problematic was also the effect of lustration and shortcomings of the lustration process, which applied only to certain position, but not to all. Many of former collaborators simply moved to positions, which were influential, but the lustration laws did not apply to them. And even if applicable, the information from secret police files was hard to verify. Moreover, the information was often incomplete, as more than 
ten percent of the registers were destroyed by the StB in the first days after the 17 November 1989 revolution or the documents simply vanished (ŠIKLOVÁ, 1999, p. 250). ${ }^{7}$ The potential of lustration to split the society and to destroy lives also of innocent people created dramatic moral dilemmas.

Even today, more than 25 years after the end of communist rule in Central and Eastern Europe, the issue of revealing and identifying persons, who collaborated with secret police and are currently working in high profile public service positions, gives rise to controversies. A current example is the case Saure v. Germany ${ }^{8}$ before the European Court for Human Rights in Strasbourg. The case concerns Hans Wilhelm Saure, a journalist working for the German newspaper BILD, who requested on 8 July 2011 from the Ministry of Justice of the Land Brandenburg precise information (names, working positions, available incriminating material) on justices and public prosecutors, who collaborated with the STASI before 1989 and are still working in the public service. In the course of domestic judicial proceeding, the respective Ministry of Justice made available parts of the requested information (e.g. number and working positions), but refused to release the identity of the persons concerned. Consequently, Mr. Saure claims violation of Article 10 ECHR, questioning, among others, whether the refusal to provide also remaining information which he asked for, was in line with the "necessary in a democratic society" requirement as required by the Article 10(2) ECHR.

\subsection{Prosecution of Crimes of The Communist Past}

\subsubsection{Applicable Law - How to Overcome Nullum Crimen Sine Lege Praevia Trap?}

One of the most troublesome issues in prosecution of crimes of the past concerns the choice of applicable law (QUILL, 1996, p. 174). Any effort to prosecute communist crimes must conform to the principle of legality: criminal proceedings can only take place when acts were punishable under the law in force at the time when these acts occurred (nullum crimen sine lege praevia) (GALLANT, 2010, p. 438-441). The principle of legality, enshrined as an absolute human right in all international human rights catalogues, ${ }^{9}$ does not distinguish between domestic and international law and provides that criminalization might stem from any legal system. It is therefore up to every single State to choose a legal framework which best serves purposes

\footnotetext{
Destruction of Secret Police documents began in Czechoslovakia already on the day when the Velvet Revolution began - November 17. In East Germany, the situation was similar, as shredding of the documents was carried out mainly in November and December 1989. When German citizens entered the STASI building (Ministerium für Staatssicherheit) in January 1990, they found more than 16000 bags of destroyed or shredded documents. Cf. The Agency of the Federal Commissioner for the Stasi Records (BStU) (2014).

8 Saure v. Germany. ECHR, Appl. n. 78944/12.

9 Article 11(2) UDHR, Article 15(1) ICCPR, Article 7 ECHR, Article 9 ACHR, Article 7(2) ACHPR.
} 
of prosecution and punishment of the crimes of its own past. ${ }^{10}$ Anyway, it is necessary that applicable law respects the principle of legality. Practice and methods in prosecution of the communist crimes adopted across the CEE countries reveal considerable differences and from comparative perspective pose a unique legal laboratory.

In the Czech Republic, the domestic practice very much followed the German pattern, although the approach finally taken was not entirely identical (KÜHN, 2009). The basic presumptions adopted both by the Czech and German courts were that all acts must be evaluated on the basis of the domestic criminal law applicable at the material time, i.e. at the time of the commission of the act (KÜHN, 2009). ${ }^{11}$ Exemplary cases from the Czech Republic and Germany deal with prosecution and punishment of the border shooting of would-be escapees (BRUCE, 2009). In German trials, the accused persons (both foot-soldiers, former high ranking officials and creators of oppressive state policy, such as Fritz Streletz, Hans Kessler and Egon Krenz) argued that their convictions after the reunification of Germany were not foreseeable and alleged that the acts on account of which they had been charged did not constitute offences under the criminal law of the former East Germany. Accused persons referred to Section 27(2) of the GDR's State Borders Act which provided legal basis for permitted use of firearms against escaping persons. ${ }^{12}$ Their ex post facto criminalization, they argued, was in breach of Article 103(2) of the Basic Law (Grundgesetz) which provides for the principle of legality.

The Federal Constitutional Court (Bundesverfassungsgericht) has nevertheless dismissed the constitutional appeals and upheld the practice of German courts. It firstly referred to the famous maxim formulated by Gustav Radbruch that where a statutory provision was intolerably inconsistent with justice, that provision should be inapplicable from the outset. ${ }^{13}$ Nevertheless, the Court did not use the Radbruch formula in the end. It focused its attention instead on interpretation of municipal law that would be consistent with human rights and held that the German domestic law applicable at the material time should have been interpreted in the light of international human rights obligations of the GDR. ${ }^{14} \mathrm{Had}$ the GDR's followed this entirely foreseeable path, it would not have been necessary to open the cases in 1990s. This line of reasoning was later sanctified by the ECHR which concluded that a State

\footnotetext{
${ }_{10}$ Prosecution of the crimes of the past is of course not a self-evident outcome. Right contrary, it is usually subjected to a wider political debate which may finally prefer non-punitive measures of transitional justice. Cf. Bassiouni (2008, p. 5-6) and Hoffmann (2013, p. 230-231).

11 Cf. Bundesgerichtshof, Fifth Criminal Senate, Judgment of 3 November 1992, case no. 5 StR 370/92. Streletz, Kessler and Krenz v. Germany. ECHR, Grand Chamber, Judgment, 22 March 2001, para. 19, para. 20. Cf. K.-H. W. v. Germany ECHR. Grand Chamber, Judgment, 22 March 2001, para. 17. For the Czech jurisprudence compare e.g. High Court in Prague, Judgment of 1 October 2001 (Pavel Čada et al.)

12 The GDR's State Borders Act provided: "The use of firearms is justified to prevent the imminent commission or continuation of an offence which appears in the circumstances to constitute a serious crime. It is also justified in order to arrest a person strongly suspected of having committed a serious crime."

13 Streletz, Kessler and Krenz, para. 22.

14 The GDR ratified the ICCPR in 1974. According to the ECHR, "[...] the fact that the GDR had not transposed those provisions into its domestic law did not alter its obligations under public international law." Cf. Streletz, Kessler and Krenz, para. 22.
} 
practice such as the GDR's border-policing policy, which flagrantly infringes human rights and above all the right to life, the supreme value in the international hierarchy of human rights, cannot be covered by the protection of Article 7(1) of the European Convention. ${ }^{15}$ What is important here is the fact that criminalization of given conduct was derived from the domestic law, even though this law was constructively reinterpreted (RIVERS, 1999, p. 50-53) with respect to international legal standards.

The practice of the Czech courts shared this preliminary axiom (criminalization on the basis of municipal law), but refused to shift interpretation of the law in force at the time of the shooting at the borders towards international human rights obligations - even though Czechoslovakia was a State party to the ICCPR from 1976. ${ }^{16}$ Shooting at the borders, or more precisely at the Czechoslovakian side of the borders, was allowed by $\S 10$ of the National Security Act (286/1948 Coll.) and later by $\S 8$ of the State Borders Protection Act (69/1951 Coll.) Firearms could have been used by border guards after previous warning against persons who attempted to cross borders illegally, certain categories of persons (e.g. dangerous perpetrators of crimes $)^{17}$ could have been shot-to-death even without prior notice. No matter how bad and harsh this regulation is from the contemporary perspective, it formed applicable legal background of successor trials in the Czech Republic. Therefore, the Czech jurisprudence concerning shooting at the borders penalized only trespass of the law in force at the material time. ${ }^{18}$ That was the case if border guards conducted cross-border shooting, ${ }^{19}$ or opened the shooting without any prior warning - the latter cases remained nevertheless rather sporadic. ${ }^{20}$

In Slovakia, the prosecution of the crimes of the past generally followed the same path (i.e. prosecution on the basis of the Czechoslovak domestic law in force at the material time ${ }^{21}$ with one significant and noteworthy difference. Until 2008, no single person was prosecuted in Slovakia for killing of would-be-escapees, despite the fact that the Slovakian Nation's Memory Institute (Ústav pamäti národa) documented 42 cases of killing at the Czechoslovakian-Austrian border between 1948 and $1989 .{ }^{22}$ Slovak authorities did not prosecute even clear excesses and transgres-

\footnotetext{
15 Cf. Streletz, Kessler and Krenz, para. 87. Compare Sweeney (2013, p. 51-57).

16 Cf. 120/1976 Coll. Quoted in Kühn (2009, p. 218).

17 Cf. $\S 1$ (c) of the Order of the Minister of National Security (70/1951 Coll.)

18 Jiř́ Čepl and Milan Kubec. Regional Court in Plzeň, Judgment of 20 November 2001.

19 Cf. supra Pavel Čada case.

${ }^{20}$ Miloš Roudnický. Regional Court in České Budějovice, Judgment of 27 April 2000. Quoted in Kühn (2009, p. 219). As Lehký (2011, p. 282) writes, "[...] [n]one of [the top officials] were tried or accused. Border killings were investigated merely as excesses of individuals on the lowest level, provided that they breached the communist regulations and laws in force at the time."

21 Decision of the Regional Police Directorate in Bratislava, KRP-20/OVK-BA-2009, 31 March 2011. In this case, Slovakian police authorities considered death of Jozef Holota, who was killed by electric current during his attempt to overcome barriers at the Czechoslovak-Austrian border in 1964. According to the decision, this act cannot be described as a criminal offense because shoot-to-kill policy was permitted by law in force at the material time and therefore, the proceeding must be stayed.

22 Ústav pamäti národa. Zločiny proti ludskosti na československej hranici so západom v rokoch 1948-1989 [Crimes against humanity on the Czechoslovak border with West between 1948-1989]. Available at: <http://www.upn.gov.sk/ sk/zlociny-proti-ludskosti-na-ceskoslovenskej-hranici-so-zapadom-v-rokoch-1948-1989/>. Access in: 10 Nov. 2015.
} 
sions of the law in force at the material time. Upset with this state of affairs and facing challenge and obstacle of the statutory limitation (compare Part 3.3.2 of this contribution), the Nation's Memory Institute issued in 2008 a criminal complaint addressed to the General Prosecutor's Office (Generálna prokuratúra) where the cases of killings on the Czechoslovakian border were qualified as crimes against humanity. ${ }^{23}$ This submission worked on the following presumptions.

Firstly, killing at the Czechoslovak borders followed systematic pattern, it did not occur on random basis, it was organized from and by the highest level of state apparatus. It was widespread both from territorial and temporal perspective (crimes were committed between 1948 and 1989) therefore the contextual element of crimes against humanity (commission as part of widespread or systematic attack) was met. Secondly, the submission stressed that the requirement of war nexus, definitional element of the crimes against humanity, disappeared at the beginning of 1950 s. Communist crimes, committed clearly outside of any armed conflict, thus could have been prosecuted as crimes under international law. Thirdly, as crimes against humanity are exempted from prescription, it was possible to prosecute them even after long period of inaction. Fourthly, the submission further stressed that crimes against humanity were part of the then Czechoslovak legal order - the IMT Statute was published in the domestic law collection in 1947 (164/1947 Coll.) and the Convention on Non-Applicability of Statutory Limitations to War Crimes and Crimes against Humanity in 1974 (53/1974 Coll.) As praiseworthy as it might be, the last (fourth) submission of the Nation's Memory Institute opens some problematic issues which should be briefly commented here. ${ }^{24}$

Direct application of the IMT Statute or the 1968 Convention would not generate clear results. Domestic courts used the IMT Statute as a source of individual criminal responsibility rather rarely (e.g. Globke and Fischer case in the GDR or Barbie and Touvier case in France) and only in situations having link to the WW 2 - this is because war nexus (in the sense of connection to the WW 2) forms separate element of crimes against humanity under the IMT Statute (FERDINANDUSSE, 2009, p. 63). The IMT Statute is inapplicable to crimes committed in period 1948-1989. Usage of the 1968 Convention is no less doubtful - the object and purpose of this international treaty does not deal with establishment of individual criminal responsibility, it simply provides for an obligation on the part of state to adopt measures necessary to ensure that statutory or other limitations shall not apply to the prosecution and punishment of war crimes and crimes against humanity (Article 6). Undoubtedly, crimes against humanity committed outside the WW 2 became part of the Slovak le-

\footnotetext{
23 Cf. $\S 8$ of the Act n. 553/2002 Coll.

24 Authors of this article agree with presumptions ad 1 - ad 3. Cf. Korbely v. Hungary. ECHR, Appl. no. 9174/02, Grand Chamber Judgment, 19 September 2008, paras 78-83. In relation to prescription, cf. part 3.3.2 of this article.
} 
gal order only in 1994 (and 2002) through amendments of the Criminal Code. ${ }^{25}$ Eventually, in relation to crimes under international law, this domestic regulation could be applied retroactively, ${ }^{26}$ nevertheless only if the legal system of Slovakia contained a "[...] rule making it possible for individuals to be held accountable on the basis of international law" (BÍLKOVÁ, 2011, p. 7), "what presupposes reception of relevant international criminal rule into domestic legal order. As customary international is not incorporated into the Slovak legal system (the Slovak Constitution contains no provision similar to Article 3(1) of the Estonian Constitution from 1992 or Article 7(1) of the Hungarian Constitution of 1949), the only remaining candidates introducing criminal responsibility for crimes against humanity are international treaties (Article 7 of the Slovak Constitution). Returning to original point, both treaties referred to above provide however only weak basis for criminal prosecution of crimes committed by communist regime.

Be it as it may, the Slovak police authorities declined to accept the line of qualification presented by the Nation's Memory Institute and confirmed that killing at the Czechoslovak borders was legal according to the law in force at material time. ${ }^{27}$ The legal basis for prosecution of the crimes of the past remained limited to domestic regulations, similarly like in the Czech Republic.

The approach taken in Hungary was significantly different. After certain hesitations, crimes of the communist regime, mainly the crimes committed during the 1956 intervention of the USSR, were prosecuted through direct application of customary international criminal law (FERDINANDUSSE, 2006, p. 76-81). It has been argued in doctrine that direct application of customary international law before domestic courts presupposes fulfilment of two prerequisites (KREICKER, 2005 , p. 319). Firstly, customary international has to be incorporated into domestic legal order, i.e. it has to be integral part of domestic law. Secondly, domestic law has to accept the possibility of application of unwritten criminal law provisions. For many countries these prerequisites introduce insurmountable obstacle. To give an example, customary international has never been incorporated into the Czech, Slovak, or Czechoslovak legal order. The same holds true in respect with possible application of unwritten criminal law provisions. The Czech Charter of Fundamental Rights and Freedoms (2/1993 Coll.), which is an integral component of the constitutional system of the Czech Republic, provides for strict principle of legality (nullum crimen sine lege scripta). According to its Article 39 only a written law, in the sense of an act adopted by the Czech Parliament, may designate which conduct constitutes a crime.

\footnotetext{
${ }_{25}$ Criminal Code (140/1961 Coll.) was amended with effect from 1 October 1994 ( $\$ 259 \mathrm{a}$ - crime of torture) and with effect from 31 July 2002 ( $\$ 259 \mathrm{~b}$ - crimes against humanity).

${ }^{26}$ In Touvier, the French courts applied domestic law adopted in 1964 to crimes against humanity committed in 1944, in Kolk and Kislyiy, the Estonian courts applied law enacted in 1994 to crimes against humanity committed in 1949. In both cases, this approach was endorsed by the ECHR. Cf. Bílková (2011, p. 7-8).

27 Regional Police Directorate in Bratislava, KRP-20/OVK-BA-2009, 31 Mar. 2011.
} 
In Hungary, the Constitutional Court set the path enabling prosecution of the crimes committed during the 1956 invasion by its decision on war crimes and crimes against humanity delivered in 1993 (SÓLYOM; BRUNNER, 2000). The Constitutional Court relied on Article 7(1) of the 1949 Constitution which determined that the legal system of the Republic of Hungary accepts the generally recognized principles of international law, and shall harmonize the country's domestic law with the obligations assumed under international law. Customary international law thus became automatically part of the Hungarian legal order. The Court continued that while crimes against humanity and war crimes are "[...] undoubtedly part of customary international law; they are general principles recognized by the community of nations" (SÓLYOM; BRUNNER, 2000) ${ }^{28}$ they can be applied directly before the Hungarian courts. In relation to the principle of legality, the Court rigorously separated international regulation (Article 7(2) ECHR, Article 15(2) ICCPR) from its domestic counterpart (Article 57(4) Hungarian Constitution) and held that the prosecution of war crimes and crimes against humanity is governed only by the principle of legality under international law (SÓLYOM; BRUNNER, 2000) ${ }^{29}$ Following the interpretation by the Constitutional Court, the prosecutorial authorities initiated investigation in more than 40 cases originating in 1956 invasion. However, only nine persons were formally indicted and only three were finally sentenced (HOFFMANN, 2003, p. 234). These low numbers may be attributed to practical obstacles (e.g. age of accused persons, obtaining evidence) criminal authorities faced in prosecution of crimes committed nearly 40 years ago (UDVAROS, 2002, p. 284).

At the same time, many cases suffered from serious flaws in legal argumentation what diminished their persuasiveness. For example the Budapest Metropolitan Court concluded that shooting at the Kossuth Square on 25 October 1956 (i.e. before the intervention by the USSR) should be classified among others with reference to Article 2 of the Geneva Convention IV which is applicable only with respect to international armed conflicts. Other problems arose from confusing blending of war crimes and crimes against humanity that had been presented already in the referred decision of the Constitutional Court (SÓLYOM; BRUNNER, 2000) ${ }^{30}$ and later followed as a template by the Hungarian criminal courts. In a fact, every criminal act committed during the 1956 revolution (and before the Soviet intervention on 4 November 1956) "[...] was to be regarded as a violation of Common Article 3 and hence a crime against humanity." (HOFFMANN, 2002, p. 242). This distorted logic led to

\footnotetext{
${ }_{28}$ See Section V.

29 See Section IV. Compare Ferdinandusse (2006, p. 79). Article 57(4) of the Hungarian Constitution (1949) referred to the principle of legality only in its nullum crimen sine lege praevia form (no one shall be declared guilty and subjected to punishment for an offense that was not a criminal offense under Hungarian law at the time such offense was committed), it did not mentioned requirement of written criminal provision (nullum crimen sine lege scripta). Nevertheless, even if there had been such domestic provision, according to the logic of the Constitutional Court's decision, it would not have been applicable in cases of core crimes.

30 See section IV, 4(b).
} 
convictions for violations of Common Article 3 qualified as crimes against humanity. Legal chaos was further accentuated by the fact that the Hungarian courts frequently did not conduct any assessment of the constituent elements of crimes against humanity at all. In Korbely v. Hungary, the ECHR concluded that this approach was problematic with respect to foreseeability of criminal conviction and contributed to declared violation of Article 7 ECHR. ${ }^{31}$

Choice of applicable legal framework had significant impact on the outcome of prosecution of crimes of the communist past in the CEE region. The ultimate aim, i.e. prosecution and punishment, might have been reached in all analyzed countries. In Hungary, legal preconditions were advantageous due to constitutional incorporation of customary international law that permitted subsequent direct application of international rules. Other countries might have followed the German pattern (i.e. application of domestic law constructively reinterpreted with reference to international human rights law). The Czech Republic and Slovakia nevertheless opted for its own path. Even if outcome of criminal prosecution of crimes of the past is rather disappointing here, especially in relation to Slovakia, it must be accepted as an expression of sovereign will of these States.

\subsubsection{Prescription}

Another legal obstacle in prosecution of crimes of the former communist regimes concerned issue of statutory limitations. Once again, from comparative perspective, each of the monitored countries used different model how to overcome this hurdle.

In 1993, the Parliament of the Czech Republic adopted act on the illegality of the communist regime and resistance to it (198/1993 Coll.) which provided for suspension of statutory limitations for crimes that had not been prosecuted for political reasons. ${ }^{32}$ This enactment was inspired by similar regulation adopted in Germany (KOK, 2007, p. 195). ${ }^{33}$ Soon after adoption of this act, its constitutionality was challenged before the Czech Constitutional Court. Applicants (members of the Czech Communist Party) argued that subsequent suspension of prescription period is in breach of principle of legality as enshrined in Article 40(6) of the Czech Charter of Fundamental Rights and Freedoms. The Constitutional Court dismissed this argumentation pointing to the fact that "[...] integral parts of criminal prescription are will, effort and willingness of State to prosecute crimes [...] if State refuses to conduct criminal prosecution, prescription is senseless: in such ca-

\footnotetext{
31 Korbely v. Hungary, para. 85.

32 The relevant part of the act provides: "The period of time from 25 February 1948 until 29 December 1989 shall not be counted as part of the limitation period for criminal acts, if due to political reasons incompatible with the basic principles of the order of a democratic state, a person was not finally and validly convicted or the charges against him were dismissed." (KOK, 2007, p. 199).

${ }_{33}$ Similar legislation was enacted also in Poland in respect of communist crimes involving human rights violations between 1939 and 1989 .
} 
ses, prescription is a mere fiction." ${ }^{34}$ In Polednová v. Czech Republic, this approach was endorsed by the ECHR. ${ }^{35}$ The conclusion of the Constitutional Court brought about diverse results, different courts and judges adopted conflicting (affirmative and deprecatory) decisions. ${ }^{36}$ By the amendment of the Criminal Code (327/1999 Coll.) effective from 28 December 1999, the Czech Parliament went even one step further and legislated that crimes committed between 1948 and 1989 are excluded from prescription for good. This extended rule, now embedded in $\S 35 \mathrm{c}$ of the Criminal Code (40/2009 Coll.), has never been formally assessed by the Constitutional Court, nevertheless in the light of previous development one may expect its constitutional sustainability. ${ }^{37}$

In Slovakia, the same pattern like in Germany and the Czech Republic was followed. In 1996, the Slovak Parliament adopted act on immorality and illegality of communist system (125/1996 Coll.) In $\S 4(1)$ this act provided that "[...] the period of time from 25 February 1948 until 29 December 1989 shall not be counted as part of the limitation period for criminal acts whose punishability has not yet terminated, if due to political reasons incompatible with the basic principles of the order of a democratic state, a person was not finally and validly convicted or the charges against him were dismissed." Comparing to the Czech regulation, there is only one slight but significant difference in wording: prescription is retroactively suspended only in relation to criminal acts whose punishability has not yet terminated (mostly due to expiration of prescription period). Therefore, contrary to the Czech Republic, if crimes committed by the communist regimes had been already statutorily barred before the act on immorality and illegality of communist system became effective (27 April 1996), it was not possible to prosecute them. Exactly for this reason, the Nation's Memory Institute suggested qualification of crimes committed at the Czechoslovak border as crimes against humanity as these crimes are not subjected to statutory limitation. Nevertheless, as it was described above, this attempt failed (cf. supra).

In Hungary, problem with statutory limitations was resolved once again entirely differently. The Hungarian authorities focused primarily on crimes committed during the 1956 revolution. In 1991, the Hungarian Parliament adopted act (Zétényi-Takács Act) which retroactively suspended prescription of crimes committed in the period between 21 December 1944 and 2 May 1990 if they were not punished due to political reasons (KOK, 2007, p. 202). In subsequent constitutional review, the Hunga-

\footnotetext{
${ }^{34}$ Czech Constitutional Court, Pl. ÚS 19/93, 21 December 1993.

35 Polednová v. Czech Republic. ECHR, Appl. n. 2615/10, Fifth Section, Decision on Admissibility, 21 June 2011. In relevant part, the ECHR concluded: "The Court accepts that, with the above-mentioned provision, the Czech State was trying to remedy a problem which it considered prejudicial to its democratic regime, and distance itself from an unacceptable practice of the totalitarian regime which allowed serious violations of its own legislation to go unpunished; thus, such an approach by the Czech legislature does not seem prima facie incompatible with the values protected by the Convention."

${ }^{36}$ For concurring rulings cf. Supreme Court, 4 Tz 44/2002, Decision of 28 February 2002 and Supreme Court, 7 Tz 44/2002, Decision of 28 August 2002. Practice of the Supreme Court was unified and coordinated with the decision of the Constitutional Court only in 2005 - cf. Supreme Court, Grand Panel, 15 Tdo 163/2005, Decision of 7 April 2005.

37 Cf. Czech Constitutional Court, III ÚS 1318/12, Decision of 26 July 2012 (obiter dictum).
} 
rian Constitutional Court quashed this legislation for its incompatibility with principle of legality and principle of legal certainty. After the dismissal of other two unconstitutional legislative proposals concerning prescription, the Hungarian Constitutional Court assessed a statute of 16 February 1993 entitled The Procedure to Follow in Case of Certain Crimes Committed During the 1956 War of Independence and Revolution. To overcome obstacle of statutory limitation, the Hungarian Parliament relied for the first time on crimes against humanity, where prescription was supposedly no longer an issue (HOFFMANN, 2002, p. 232). In the seminal decision, which has already been analyzed in the previous section, the Constitutional Court concluded:

The 1968 New York Convention on the non-applicability of statutory limitations for the punishment of war crimes and crimes against humanity, as well as the 1974 European Convention addressing a similar subject matter, may not be regarded as part of customary international law or a generally recognized principle of international law. But those states which ratified either one of the two conventions assumed the international obligation to declare, even with retroactive force, that the statutes of limitation may never expire with respect to the war crimes and crimes against humanity enumerated in the convention. (SÓLYOM; BRUNNER, 2000). ${ }^{38}$

Hungary as a state party to the 1968 New York Convention was thus under legal obligation not to apply domestic statutory limitations for war crimes and crimes against humanity. As crimes committed during the 1956 revolution were qualified as war crimes and crimes against humanity, the obstacle of prescription was effectively removed. Nevertheless, the Constitutional Court suggested some legislative corrections should have been taken before promulgating the act (KOK, 2007, p. 207) (e.g. the act provided that grave breaches of the Geneva Conventions apply even in non-international armed conflicts). Surprisingly, the story did not end up here: as the Hungarian legislator failed to address the Constitutional Court's concerns, the act was quashed in $1996 .{ }^{39}$ The Parliament amended it correctly and in compliance with the Constitutional Court's opinion only in 1996.

As has been shown, the sensitive question of retroactive application of statutory limitations was addressed differently in the CEE countries. The brief analysis confirms that states have wide margin of appreciation in prosecution of crimes of the past. In Hungary, retroactive suspension of statutory limitations was not permitted, nevertheless prosecution of crimes of the communist past was granted through application of customary international criminal law. In the Czech Republic, the situation was reversed - retroactive suspension of statutory limitations was approved, but effective prosecution of crimes was limited by applicable legal framework (domestic

\footnotetext{
38 Hungarian Constitutional Court, Decision n. 53/1993, section V, 3. Whether non-applicability of statutory limitations to war crimes and crimes against humanity (or more generally to crimes under international law) is a rule of customary character falls out of the ambit of this article. For detailed analysis cf. Kok (2007, p. 311-338).

39 Hungarian Constitutional Court, Decision n. 36/1996, 4 November 1996.
} 
law in force at the material time). In Slovakia, despite significant attempt to qualify crimes of the communist past as crimes against humanity, no prosecution took place at all. Here, prescription proved to be an insurmountable obstacle as the legislator refused to retroactively suspend statutory limitations with respect to crimes of the past that have already been time-barred.

\section{Conclusion}

Dealing with the communist crimes constitutes an important element of transitional justice in Central and Eastern Europe. Countries, which on their way to democratic societies decided to cope with their past not by forgetting and pardoning the past injustice, but by prosecuting and punishing it, did so in three main ways: opening of the archives, lustration and prosecution. When comparing these three means, prosecution constitutes the most controversial one. It of course shares the problems with lustration and opening of archives, but is stronger in its impact, as it does not only lead to social denunciation or loss of social status, but tends to interfere with individuals' rights in a particularly intensive way, e.g. by depriving the person of its liberty through imprisonment. It was stressed that the attempts to condemn and punish wrongs of the past (which often had legal authorization under the then existing legal system), the attempts to satisfy the victims of the former regime, face the problem of being potentially in conflict with central elements of the rule of law: the principle that law does not act retrospectively, no punishment without a legally defined crime (nulla poena sine lege), no crime without a pre-existing law (nullum crimen sine praevia lege poenali). While dealing with the legal challenge concerning prosecution of crimes of the communist past, the CEE countries showed significant flexibility. Despite differences in applicable law, including treatment and interpretation of statutory limitations, and differences in overall outcomes of prosecution and punishment of the communist crimes, all countries covered in this contribution shared an opinion that to disregard these fundamental principles of criminal justice is simply not possible, as leaving them aside would destroy the idea of the rule of law and would amount at best to victor's justice, at worst to a witch hunt, both being in a harsh contradiction with the overall aims, ideals and fundaments of the process of transition to democracy and rule of law.

\section{References}

THE AGENCY OF THE FEDERAL COMMISSIONER FOR THE STASI RECORDS (BStU). Rekonstruktion zerrissener Unterlagen. 12 Aug. 2014. Available at: $<$ http://www.bstu.bund.de/DE/Archive/RekonstruktionUnterlagen/_node.html >. Access in: 10 Nov. 2015.

ASLUND, Anders. Building Capitalism: The Transformation of the Former Soviet Bloc. Cambridge: CUP, 2001. 
BASSIOUNI, Cherif. International Criminal Law. International Enforcement. Leiden: Martinus Nijhoff, 2008.

BRUCE, Gary. East Germany. In: STAN, Lavinia (Ed.) Transitional Justice in Eastern Europe and the Former Soviet Union: Reckoning with the communist past. London: Routledge, 2009.

CADA, Pavel et al. Regional Court in Plzeň, Judgment of 15 March 2001. Available at: < http://www.policie.cz/clanek/pravomocne-rozsudky.aspx>. Access in: 10 Nov. 2015 .

CASSESE, Antonio. Nullum Crimen Sine Lege. In: CASSESE, Antonio. The Oxford Companion to International Criminal Justice. Oxford: OUP, 2010.

FERDINANDUSSE, Ward. Direct Application of International Criminal Law in National Courts. Hague: T.M.C. Asser Press, 2006.

GALLANT, Kenneth. Principle of Legality in International and Comparative Law. Cambridge: CUP, 2010.

HELICHER, Brad A. Klaus's "Middle Game": Repercussions of Privatization and Democratization in the Czech Republic. In: HANCOCK, M. Donald; LOGUE, John (Ed.) Transitions to capitalism and democracy in Russia and Central Europe: achievements, problems, prospects. Greenwood Publishing Group, 2000.

HELLER, Kevin John; SIMPSON, Gerry. The Hidden Histories of War Crimes Trials. Oxford: OUP, 2013.

HOFFMANN, Tamás. Trying Communist through International Criminal Law? The Experiences of the Hungarian Historical Justice Trials. In: HELLER, Kevin John, SIMPSON, Gerry. The Hidden Histories of War Crimes Trials. Oxford: OUP, 2013.

KORNAI, Janos. The Great Transformation of Central Eastern Europe. Success and Disappointment. Economics of Transition, v. 14, i. 2, p. 207-244, 2006.

KREICKER, Helmut. National Prosecution of International Crimes from a Comparative Perspective: The Question of Genocide. International Criminal Law Review, v. 5, i. 3, p. 319, 2005.

KÜHN, Zdeněk. Zločin a trest. In: BOBEK, Michal et al. (Ed.) Komunistické právo $v$ Československu. Brno: Masarykova univerzita, 2009. [Crime and Punishment. In: The Communist Law in Czechoslovakia].

KOK, Ruth A. Statutory Limitations in International Criminal Law. The Hague: T. M. C. Asser Press, 2007. 
LEHKÝ, Miroslav. Classification of the crimes committed between 1948 and 1989 and the prosecutions of these crimes after 1990. In: LEHKÝ, Miroslav. Crimes of the Communist Regimes. Prague: The Institute for the Study of Totalitarian Regimes, 2011.

NEDELSKY, Nadya. Czechoslovakia and the Czech and Slovak Republics. In: STAN, Lavinia. Transitional Justice in Eastern Europe and the Former Soviet Union. London/New York: Routledge, 2009.

POLICIE ČESKE REPUBLIKY. The Office for the Documentation and the Investigation of the Crimes of Communism Police of the Czech Republic. 2015. Available at: $<$ http://www.policie.cz/clanek/the-office-for-the-documentation-and-the-investigation-of-the-crimes-of-communism-police-of-the-czech-republic.aspx $>$. Access in: 10 Nov. 2015.

POP-ELECHES, Grigore. Historical Legacies and Post-Communist Regime Change. The Journal of Politics, v. 69, i. 4, p. 908-926, 2007.

QUILL, Adrienne. To Prosecute or Not To Prosecute: Problems Encountered in the Prosecution of Former Communist Officials in Germany, Czechoslovakia, and the Czech Republic. Indiana International and Comparative Law Review, v. 7, i. 1, p. 174, 1996.

RIVERS, Julian. The Intepretation and Invalidity of Unjust Laws. In: DYZENHAUS, David (Ed.) Recrafting the Rules of Law: The Limits of Legal Order. Oxford: Hart Publishing, 1999.

ŠELIH, Alenka. Crime and Crime Control in Transition Countries. In: ŠELIH, Alenka, ZAVRŠNIK, Aleš (Ed.) Crime and Transition in Central and Eastern Europe. New York: Springer, 2012.

ŠIKLOVÁ, Jiřina. Lustration or the Czech Way of Screening. In: KRYGIER, Martin, CZARNOTA, Adam (Ed.) Rule of Law After Communism. Sydney: Ashgate, 1999.

SÓLYOM, László; BRUNNER, Georg. Decision n. 53/1993, On War Crimes and Crimes Against Humanity, 13 Oct. 1993. In: SÓLYOM, L; BRUNNER, G. Constitutional Judiciary in a New Democracy. The Hungarian Constitutional Court. Michigan: The Michigan University Press, 2000.

SWEENEY, James A. The European Court of Human Rights in the Post-Cold War Era: Universality in Transition. London: Routledge, 2013.

TEITEL, Ruti G. Transitional Justice. New York: OUP, 2000.

TISMANEANU, Vladimir. Foreword. In: STAN, Lavinia. Transitional Justice in Eastern Europe and the Former Soviet Union. London/New York: Routledge, 2009. 
UDVAROS, Judit. Ungarn. In: Strafrecht in Reaktion auf Systemunrecht: Polen, Ungarn. Freiburg: Ed. Iuscrim, p. 284, 2002.

\section{Judgments and other documents:}

BÍLKOVÁ, Veronika. Amicus curiae brief for the Constitutional Court of Peru. Venice Commission, Opinion, n. 634, p. 7-8, 15 Sept. 2011.

Bundesgerichtshof, Fifth Criminal Senate, Judgment of 3 November 1992, case no. 5 StR 370/92.

Czech Constitutional Court, III ÚS 1318/12, Decision of 26 July 2012.

Czech Constitutional Court, Pl. ÚS 19/93, 21 December 1993.

High Court in Prague, Judgment of 1 October 2001 (Pavel Čada et al.).

Korbely v. Hungary. ECHR, Appl. no. 9174/02, Grand Chamber Judgment, 19 September 2008.

Hungarian Constitutional Court, Decision n. 53/1993, On War Crimes and Crimes Against Humanity, 13 October 1993.

Hungarian Constitutional Court, Decision n. 36/1996, 4 November 1996.

Jiř́ Čepl and Milan Kubec. Regional Court in Plzeň, Judgment of 20 November 2001.

K. -H. W. v. Germany, ECHR, Grand Chamber, Judgment, 22 March 2001.

Miloš Roudnický. Regional Court in České Budějovice, Judgment of 27 April 2000.

Polednová v. Czech Republic. ECHR, Appl. No. 2615/10, Fifth Section, Decision on Admissibility, 21 June 2011.

Regional Police Directorate in Bratislava, KRP-20/OVK-BA-2009, 31March 2011.

Saure v. Germany. ECHR, Appl. n. 78944/12.

Streletz, Kessler and Krenz v. Germany, ECHR, Grand Chamber, Judgment, 22 March 2001 .

Supreme Court, 4 Tz 44/2002, Decision of 28 February 2002.

Supreme Court, 7 Tz 44/2002, Decision of 28 August 2002. 
Supreme Court, Grand Panel, 15 Tdo 163/2005, Decision of 7 April 2005.

Data da submissão: 22 de dezembro de 2015 Avaliado em: 23 de dezembro de 2015 (Avaliador A) Avaliado em: 28 de dezembro de 2014 (Avaliador B) Aceito em: 30 de dezembro de 2015 